\title{
MICROCOSM TESTING OF MUNICIPAL SEWAGE AND GREEN WASTE FOR FULL-SCALE REMEDIATION OF AN ACID COAL PIT LAKE, IN SEMI-ARID TROPICAL AUSTRALIA ${ }^{1}$
}

\author{
Clint D. McCullough ${ }^{2}$, Mark A. Lund, and Joel M. May
}

\begin{abstract}
Pit lakes (abandoned flooded mine pits) represent a potentially valuable water resource to mining companies, the environment and regional communities across arid inland Australia. However, the water is often of low $\mathrm{pH}$ with high dissolved metal concentrations.

The addition of organic matter to the pit lakes to enhance microbial sulfate reduction is potentially a cost effective and sustainable remediation strategy for these acid waters. However, the cost and availability of sufficient quantities of suitable organic substrates is typically limiting in these remote regions. Nevertheless, small quantities of sewage and green waste (organic garden waste) are often available in these areas from the regional towns which support the mines. This paper reports on preliminary microcosm laboratory experiments in preparation for the treatment of an acid $(\mathrm{pH} 2.2)$ coal mine pit lake in semi-arid tropical, inland north Queensland, Australia with municipal treated sewage and green waste.

A laboratory experiment using microcosms (acrylic tubes) containing acid pit lake water and sediment were treated as follows; controls (untreated), sewage, green waste and sewage and green waste. The $\mathrm{pH}$ increased to a maximum of 5.5 in 145 days in the green waste and sewage treatment, with notable decreases of iron, aluminium and toxic heavy metals. Our results indicated that the green waste was a key component in alkalinity production and heavy metal removal.
\end{abstract}

Additional Key Words: acid mine drainage, pit lakes, sulfate reduction, wetland, organic matter.

${ }^{1}$ Paper presented at the $7^{\text {th }}$ International Conference on Acid Rock Drainage (ICARD), March 26-30, 2006, St. Louis MO. R.I. Barnhisel (ed.) Published by the American Society of Mining and Reclamation (ASMR), 3134 Montavesta Road, Lexington, KY 40502

${ }^{2}$ Clint McCullough is a Research Fellow at the Centre for Sustainable Mine Lakes (CSML) and Mark Lund is a Senior Lecturer at the Centre for Ecosystem Management (CEM), Edith Cowan University, 100 Joondalup Drive, Perth, WA 6027, Australia. Joel May is the Environmental Advisor at the Collinsville Coal Mine managed by Xstrata Coal Queensland, P.O. Box 60, Collinsville, Qld 4804, Australia.

$7^{\text {th }}$ International Conference on Acid Rock Drainage, 2006 pp 1177-1197

DOI: $10.21000 / J A S M R 06021177$

https://doi.org/10.21000/JASMR06021177 


\section{Introduction}

Microbial sulfate $\left(\mathrm{SO}_{4}{ }^{-2)}\right.$ reduction is considered to be an efficient and effective remediation for the treatment of acid mine drainage (AMD), through alkalinity production and precipitation of metals as sulfides through reaction with sulfide cations (Equation 1) and as carbonates through increased pH (Equation 2) (Benner et al., 2002; Dillon et al., 1997; Küsel and Dorsch, 2000; Praharaj and Fortin, 2004). In-lake neutralisation via $\mathrm{SO}_{4}{ }^{-2}$ reduction is expected to play a keyrole in the remediation of acidic mining pit lakes (Kleeberg, 1998). However, since Tuttle et al. (1969) first suggested the use of $\mathrm{SO}_{4}{ }^{2-}$ reducing bacteria (SRB) in the treatment of AMD, treatment has largely focused on ex-situ treatment in bioreactors. What in-situ treatment relevant experiments have occurred have generally been performed at microcosm (e.g., carboy vessels; (Castro et al., 1999; Frömmichen et al., 2004; Fyson et al., 1998)) or at best macrocosm (e.g., limnocorrals) scales (Martin et al., 2003). It is largely recently that attention has switched to insitu remediation systems at actual field treatment scales (Gibert et al., 2002).

Equation 1

$$
\mathrm{Metal}^{+2}+\mathrm{SO}_{4}^{-2}+2 \mathrm{C}_{(\text {organic })} \rightarrow \text { MetalS }+2 \mathrm{CO}_{2}
$$

Equation 2

$$
\mathrm{Metal}^{+2}+\mathrm{CO}_{3}^{-2} \rightarrow \mathrm{MetalCO}_{3}
$$

A review by Gibert et al. (2002) found that the nature of the organic matter was a prime determinator of the efficacy of the passive treatment system. For example, the availability of carbon from plant matter is dependent upon decomposition, which is extremely limited in acidic and anoxic conditions (Harris and Ragusa, 2001). To this end, Waybrant et al. (1998) found mixtures containing multiple sources of organic matter demonstrated higher $\mathrm{SO}_{4}{ }^{2-}$ reduction rates than those of single sources. Castro and Moore (1997) observed that, "Therefore, for economic feasibility the added organic matter must be cheap and locally available." Hard et al. (2003) echoed this view noting that, "For a microbial process to be economically feasible, the carbon (C) and energy source should be cheap, widely available and highly effective." However, most experiments into the utility of $\mathrm{SO}_{4}{ }^{-2}$ reduction processes for ameliorating AMD have instead focused upon highly labile but expensive $\mathrm{C}$ substrates such as ethanol (Kolmert and Johnson, 2001; Martin et al., 2003; McNee et al., 2003), sugar (Frömmichen et al., 2003; Frömmichen et al., 2004; Geller et al., 2003; Pöhler et al., 2002; Wendt-Potthoff et al., 2002), cow manure (Drury, 1999; Drury, 2000), etc. For many remote mining locations, these materials are unviable for practical and economic reasons. The only bulk $\mathrm{C}$ sources likely to be available in these areas will be municipal sewage, and green waste (including a broad range of plant material collected by local government from domestic and municipal lawns and gardens).

Using readily-available and economically-viable sources of organic materials, Waybrant et al. (1998) found all of the eight organic matter types they tested reduced $\mathrm{SO}_{4}{ }^{-2}$, with sewage sludge the fastest to achieve high levels of sulfate reduction. The mixture of sewage sludge and green waste (leaf mulch, woodchips and sawdust) reduced $4,500 \mathrm{mg} \mathrm{L}^{-1}$ of SO$_{4}^{-2}$ to $<25 \mathrm{mg} \mathrm{L}^{-1}$ in only 35 days. Again using locally available bulk materials, a laboratory experiment by Harris and Ragusa (2000) also found a mixture of sewage sludge and plant material (fresh rye grass) was effective in initiating amelioration of acidity and metal concentrations of acid mine waters through sulfate reduction. The $\mathrm{pH}$ levels increased significantly from 2.3 to $>3$ within 30 days of SRB activation and simultaneously decreased divalent metal concentrations. This mixture proved more effective in ameliorating $\mathrm{pH}$ and metal concentrations than either sewage sludge 
(little response) or plant material (nil response). Gusek (2002) even suggested injecting sewage sludge into mine shafts and adits to remove and prevent production of acidity from these sources.

More specific data for our particular study area was reported in a 1993 study at the Collinsville Coal Project Mine in North Queensland, Australia (Fallon, 1994). Although unquantified, this report details findings that the extremely acid waters of Blake A-cut had "notably improved" (i.e. reduced acidity, $\mathrm{SO}_{4}{ }^{-2}$ and metal concentrations) and suggested that one mechanism may be bacterially-mediated $\mathrm{SO}_{4}{ }^{-2}$ reduction occurring with the sewage effluent discharged into this pit being used as a source of carbon. Rates of SRB activity may also be greater in a tropical area such as this mining location, than in the other published research, much of it originating from temperate Europe and North America.

Consequently, there is a large body of published data to suggest that bacterially-mediated sulfate reduction processes can ameliorate acid mine drainage waters. Published literature from laboratory and mesocosm experiments also indicates that sewage is suitable for use as an organic substrate stimulating $\mathrm{SO}_{4}^{-2}$ reduction. However, there are few published reports of field scale attempts of AMD lake remediation. Furthermore, very little bioremediation work has been carried out on the mining pit lakes of Australia using these methods, especially in semi-arid tropical Australia where a significant number of acid pit lakes historically occur and are still being developed of increasing sizes (Harries, 1997). As an arid continent with increasing pressure on water resources, there is growing demand for new sources of water to meet a variety of end uses (Doupé and Lymbery, 2005).

The end use of many of these pit lakes may also often be only for slightly remediated water quality of lower salinity for mining operation dust suppression or similar industrial use. Consequently, financially viable treatment to this lower standard may still be very achievable in even remote mining areas. Consequently, this research project intended to test the potential of this biotechnology to remediate a representative extremely low $\mathrm{pH}$, high-acidity and high solute concentration mining lake in a typical remote Australian mining community.

\section{Methods}

\section{Study area}

Collinsville is a typical small inland Australian mining town located approximately $70 \mathrm{~km}$ from the coast of North Queensland, Australia (Fig. 1). Together with the mining town of Scottville, Collinsville is located within a kilometre of the active mining Collinsville Coal Project coal mining lease (Fig. 2). Collinsville was underground (bord and pillar) mined for its coal as early as 1919 at the State Mine working the Bowen Seam, and began open-cast mining in the mid 1950s. Mining operations are expected to continue until 2013. The combined population of Collinsville and nearby Scottville is currently around 2,021 people (1996 census) and is undergoing a decline as mining activity declines.

Collinsville has a semi-arid tropical climate with a rainfall regime that falls into a transition between sub-humid and semi-arid. The climate is dominated by a moderately low, highly episodic and unreliable summer rainfall $(707.9 \mathrm{~mm} / \mathrm{annum})$ and a very high evaporation rate (1,860 mm/annum) (Commonwealth of Australia Bureau of Meteorology, 09/02/2005; Davies and Willcocks, 1992) (Fig. 2). 


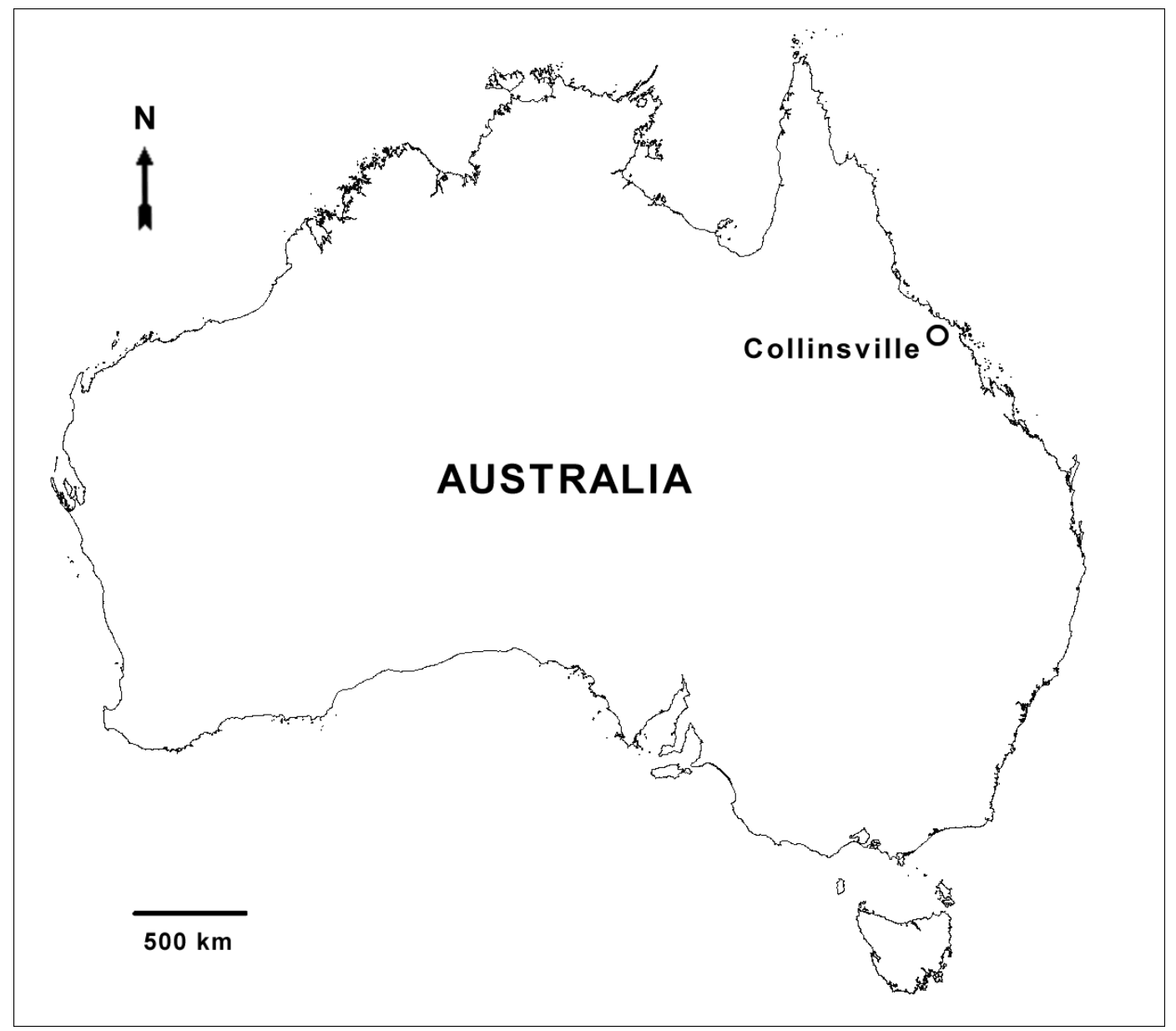

Figure 1 Location of the study site in Collinsville, North Queensland, Australia.

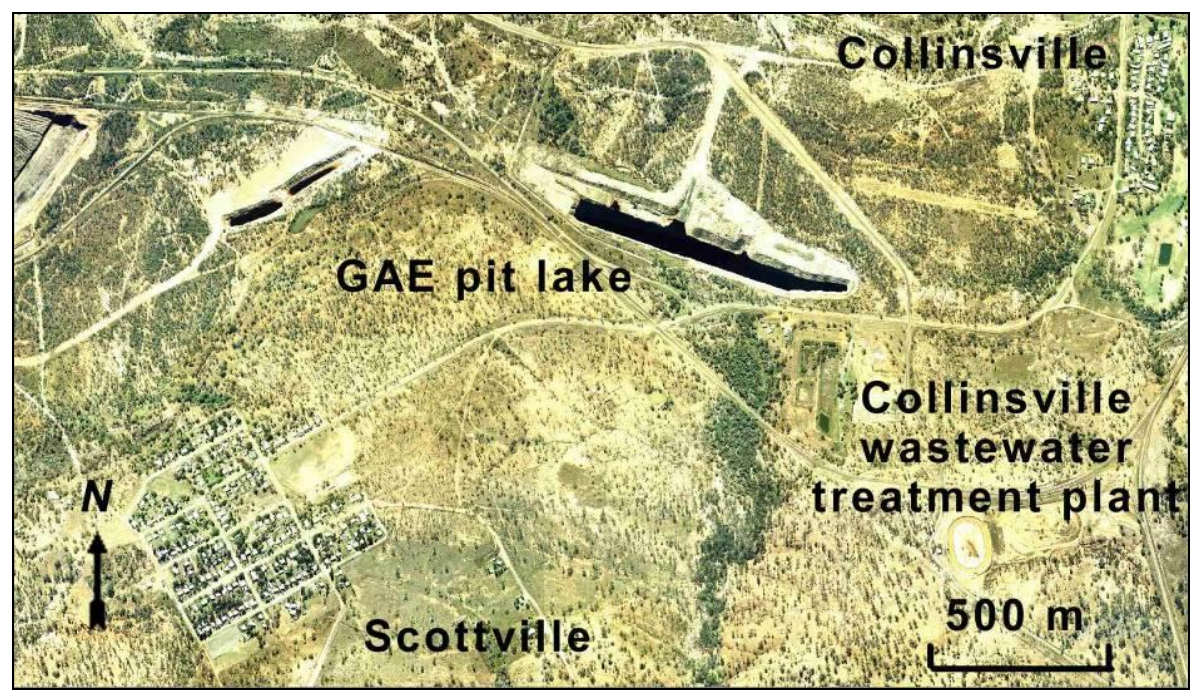

Figure 2. GAE pit lake; the source of water and sediment for this and another laboratory microcosm study, and the site of a current pit lake bioremediation field trial. 
The geology of the region is of highly weathered hard rocks with soils of very low organic carbon content. Surrounding vegetation is predominantly Eucalyptus and Acacia spp. dominated open woodland with an annual grass understorey. There are some 20 pit lakes in the Collinsville Coal Project lease, all of which are acidic with high concentrations of dissolved solutes (Fig. 3). All of these lakes are of extremely low $\mathrm{pH}(\mathrm{ca} . \mathrm{pH} 2)$ and contain high concentrations of dissolved solutes (electrical conductivity $=9-19 \mathrm{mS} \mathrm{cm}^{-1}$ ). One of these acid pit lakes, "Garrick East" (GAE), is the focus of this study due to its proximity to the Collinsville waste water treatment plant and green waste dump ( $<500 \mathrm{~m}$ away). This lake is of maximum depth $12 \mathrm{~m}$, surface area 1.3 ha and volume 120 ML (Fig. 2, Fig. 4).

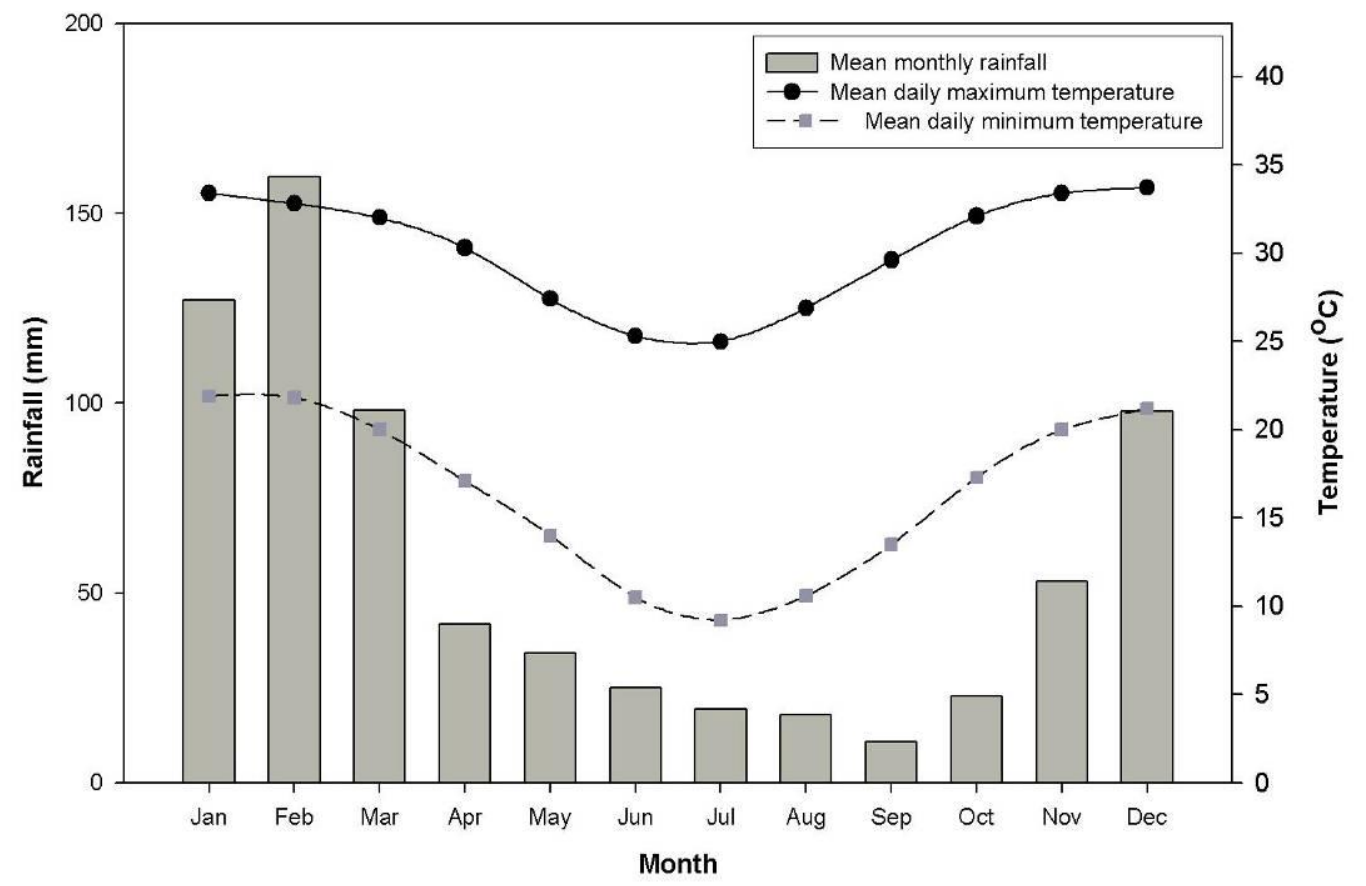

Figure 3. Mean temperature and rainfall climate of Collinsville (Commonwealth of Australia Bureau of Meteorology, 09/02/2005).

\section{Experimental design}

Microcosm experiments were designed to mimic the hypolimnetic water column and sediment regions of a typical strongly stratified Collinsville pit lake. Twelve clean $100 \mathrm{~mm}$ diameter and $600 \mathrm{~mm}$ long $(4.5 \mathrm{~L})$ acrylic tubes were set up in an uninsulated laboratory on the mine site as microcosms containing $140 \mathrm{~mm}$ of sediment and $440 \mathrm{~mm}$ of GAE pit lake water. Cores were pushed into the littoral sediment of GAE at $50 \mathrm{~cm}$ water depth and sealed with rubber bungs at the top and bottom. The height of sediment in the bottom of the core was then adjusted by sliding it downwards out the bottom of the core to a final depth of $140 \mathrm{~mm}$ across all cores. Three replicate cores were then allocated to each of the following; control (untreated), green waste only, sewage, or green waste and sewage at dosing rates realistic of that able to be achieved in a typical CCP pit lake using regional sources over a few month's filling duration. 


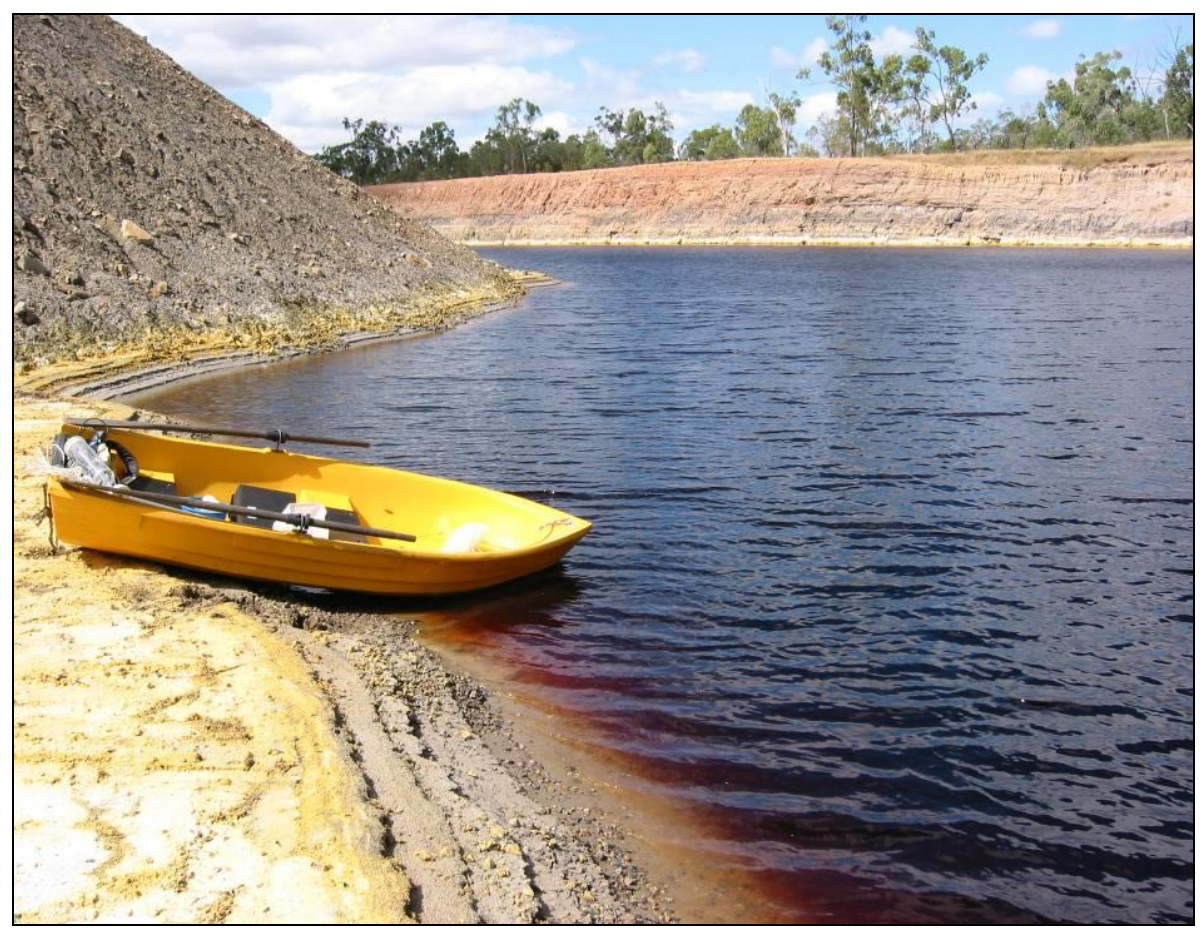

Figure 4. "Garrick East" Collinsville Coal Project mining pit lake. Note very dark orange colour of water due to high dissolved $\mathrm{Fe}$ concentrations $(\mathrm{pH}=c a .2$, electrical conductivity $=c a .9 \mathrm{mS} \mathrm{cm}^{-1}$ ), and efflorescence of elemental sulfur, gypsum and epsomite around littoral fringe.

Green waste was sourced from the Collinsville shire green waste dump nearby the Collinsville Coal Project lease. Greenwaste consisted of a wide range of garden clippings from both woody and herbaceous species that had been exposed to Dry season drying climatic conditions for some weeks. Primary-treated sewage sludge was sourced from the Collinsville Municipal Wastewater Treatment Plant. Due to the over-capacity of the plant for the declining town size, the sewage sludge had been exposed to the sun in drying beds for around 12 weeks.

The cores were then filled with GAE water to within $100 \mathrm{~mm}$ of their brim, green waste was then added where appropriate, and then sewage in the following scheme (Table 1). Microcosm core water levels were topped-up to with $20 \mathrm{~mm}$ of the core's brim and a loose-fitting rubber bung was applied to the top (not airtight) to reduce air infiltration into the core water as would a strongly stratified epilimnion (Fig. 4). The entire suite of microcosm cores were then placed in a $500 \mathrm{~mm}$ high opaque black plastic planter tub which was filled with water to evenly distribute ambient temperatures between cores and to reduce the incidence of leakage. The lower waterfilled tub was then capped with an identical inverted planter tub to occlude light, as PAR levels are extremely low in the hypolimnion of these lakes (author's unpublished data).

The cores were then sampled for the physico-chemical variables; temperature, $\mathrm{pH}$ specific conductance, oxidation-reduction potential and dissolved oxygen (\% saturation and $\mathrm{mg} / \mathrm{L})$ with a Hydrolab Quanta multiparameter meter. 
Table 1. Experimental design for organic dosing of pit lake cores.

\begin{tabular}{lccc}
\hline Treatment level & $\begin{array}{c}\text { Organic dosing } \\
\text { mass }(\mathrm{g})\end{array}$ & $\begin{array}{c}\text { Water:green } \\
\text { waste:sewage ratio }\end{array}$ & $\begin{array}{c}\text { Number of } \\
\text { replicates }\end{array}$ \\
\hline Control & 0 & $1: 0: 0$ & 3 \\
Green waste & 200 & $16: 1: 0$ & 3 \\
Green waste and sewage & 100 and 200 & $32: 1: 2$ & 3 \\
Sewage & 200 & $16: 0: 1$ & 3 \\
\hline
\end{tabular}

Physico-chemical measurements were taken at one day after filling, two days after, and then at approximately two-weekly intervals thereafter for 145 days.

A $100 \mathrm{~mL}$ water sample was taken after 82 days and analysed for concentrations of solutes. Cations (Al, As, $\mathrm{Br}, \mathrm{Ca}, \mathrm{Cd}, \mathrm{Cr}, \mathrm{Co}, \mathrm{Cu}, \mathrm{Fe}, \mathrm{Pb}, \mathrm{Mg}, \mathrm{Hg}, \mathrm{SO}_{4}^{-2}, \mathrm{Se}, \mathrm{Si}, \mathrm{Sn}, \mathrm{Zn}$ ) were analysed via ICP-AES. Ammonium and NOx (nitrate and nitrite) anions were analysed on an auto-analyser using the Berthelot and persulfate digestion methods respectively, with subtraction (APHA, 1998).

Primary treated municipal sewage was collected from drying beds of the Collinsville Water Treatment Plant. Due to a very low output from the plant, this material had been dried for around 12 weeks and was thus of an extremely low water content (sewage density $=1.35 \mathrm{~kg} / \mathrm{L}$ ). A sample from this sewage collection was taken for analysis.

Green waste was collected from the Collinsville green waste tip. This material was largely representative of Australian garden waste and included lawn clippings, palm fronds and other leafy and woody material. Green waste was chopped into approximately $50 \mathrm{~mm}$ sections to fit into the cores. As Western Australia Custom's horticultural restrictions prevent importation of green waste from Queensland, a representative sample of green waste was prepared in Perth from similar local plants and was dried at $25^{\circ} \mathrm{C}$ for one week to simulate ambient conditions at Collinsville municipal green waste dump. The sewage and green waste samples were then analysed for total $\mathrm{N}$, total $\mathrm{P}$ and total organic $\mathrm{C}$ content as well as for the same suite of cations as the solid sewage sample via ICP-AES.

Statistical analyses

Hypothesis testing of univariate data was carried out in SPSS (2000) by one way Analysis of Variance (ANOVA) following $\log _{10}$ transformation and testing for normality of distribution and homogeneity of variance. If a significant difference was detected at $\alpha=0.05$ level, post-hoc tests were made with Dunnett's multiple comparison test against the control group.

Multivariate wet chemistry data and physico-chemical data from day 86 was analysed by Principal Components Analysis (PCA) in the PRIMER software package (PRIMER-E Ltd, 2001). Prior to analysis, draftsman plots were created to determine which variables were highly (i.e., 95\% or greater) Spearman rank-correlated with each other. These variables were then deleted to leave only a single dummy variable which then represented all of these correlated variables. For example, the two variables dissolved $\mathrm{O}_{2}(\%)$ and dissolved $\mathrm{O}_{2}(\mathrm{mg} / \mathrm{L})$ were reduced to just dissolved $\mathrm{O}_{2}(\%)$ to form a dummy variable "dissolved $\mathrm{O}_{2}$ " representing an index 
of the availability of dissolved $\mathrm{O}_{2}$. Data were then $\log _{10}$ transformed to enhance a linear relationship between variables and finally normalised to account for different variable scales (Clarke and Warwick, 2001).

\section{$\underline{\text { Results }}$}

Garrick East pit lake had a very low $\mathrm{pH}$ and high total Fe concentrations indicative of an Fe buffered system (Table 2), with heavy metals at environmentally toxic concentrations (ANZECC/ARMCANZ, 2000). Nutrient levels were also very low in this pit lake; especially for $\mathrm{P}$ as is typical of AMD waters (Borg and Holm, 2001; Lessmann et al., 2000).

Collinsville sewage sludge was high in $\mathrm{S}\left(10,000 \mathrm{mg} \mathrm{kg}^{-1}\right)$ and also contained notable levels of $\mathrm{Al}\left(2,700 \mathrm{mg} \mathrm{kg}^{-1}\right), \mathrm{Fe}, \mathrm{Ca}$ and $\mathrm{Mg}$. However, concentrations of some heavy metals including

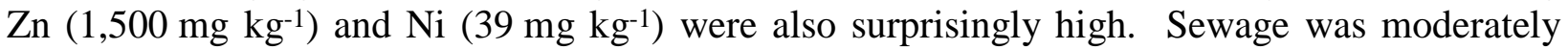
high in $\mathrm{N}\left(31 \mathrm{mg} \mathrm{kg}^{-1}\right)$ and $\mathrm{P}\left(12 \mathrm{mg} \mathrm{kg}^{-1}\right)$, had relatively high organic $\mathrm{C}$ content $(29 \%)$ and contributed significant alkalinity to the dosed AMD water (Table 2).

Although green waste contributed less alkalinity to the AMD water, it contained the highest percentage of organic C $(31 \%)$. Green waste also contained moderate amounts of $\mathrm{S}\left(1,700 \mathrm{mg} \mathrm{kg}^{-1}\right), \mathrm{N}\left(20 \mathrm{mg} \mathrm{kg}^{-1}\right)$ and $\mathrm{P}\left(2.3 \mathrm{mg} \mathrm{kg}^{-1}\right)$. Although $\mathrm{Ca}$ and $\mathrm{Mg}$ levels were higher in green waste compared to sewage, heavy metal concentrations were very low.

Although the control treatment looked largely unchanged over the course of the experiment, the green waste treatment had darkened considerably; probably through leaching of labile organic material and with a sweet odour indicative of fermentation processes. The presence of this process was further reinforced by the development of a blue-green coloured mould on the surface of both the green waste treatment and on the green waste and sewage treatment throughout the experiment (Fig. 5). The sewage treatment became more orange in colour, although when inspected from above this was found to be due to a precipitate (probably $\mathrm{Fe}$ ) settling on the inside of the acrylic tube. The water in the sewage treatment appeared to have lost the orange tinge which the control cores still retained. The space between the greenwaste and sewage and the sediment surface began to blacken in the green waste and sewage treatment after only a few weeks of the experiment beginning. After Castro et al. (1999), this black material was assumed to be $\mathrm{Fe}^{+2}$ sulfides from the activities of $\mathrm{SO}_{4}{ }^{-2}$ reducing bacteria, as the space above the mesocosm sediments of this treatment which were likely to be highly anaerobic. A strong sulfide smell, presumed to be hydrogen sulfide, also evolved as the black precipitate extended upwards through the mesocosm above the green waste and sewage solids. This sulfide

smell and the commiserate presence of a black precipitate indicated that $\mathrm{SO}_{4}{ }^{-2}$ reduction was occurring in these green waste treatments.

Two days after addition of organic substrates to AMD cores there was a statistically significant mean increase in $\mathrm{pH}$ above the control for the treatments of green waste and sewage, and sewage $\left(\mathrm{F}_{3,8}=23.060, \mathrm{p}<0.001\right)$ (Fig. 6). Green waste alone also showed a slight increase in $\mathrm{pH}$, although this was not significant $(\mathrm{p}>0.05)$. All treatments also showed a significant decrease in redox compared to the control $\left(\mathrm{F}_{3,8}=16.673, \mathrm{p}=0.001\right)$. 
Table 2. Chemistry of GAE pit lake water and organic materials used in core experiments.

\begin{tabular}{|c|c|c|c|}
\hline Parameter & $\begin{array}{c}\text { GAE water } \\
(\mathrm{mg} / \mathrm{L})\end{array}$ & $\begin{array}{l}\text { Sewage } \\
(\mathrm{mg} / \mathrm{Kg})\end{array}$ & $\begin{array}{c}\text { Green waste* } \\
(\mathrm{mg} / \mathrm{Kg})\end{array}$ \\
\hline Total sulfur & No data & 10,000 & 1,700 \\
\hline Sulfate & 2,610 & No data & No data \\
\hline Total nitrogen & 0.51 & п31 & п20 \\
\hline Total phosphorus & $<0.5$ & 12 & 2.3 \\
\hline Total organic carbon & No data & $29 \%$ & $39 \%$ \\
\hline $\mathrm{pH}$ & 2.4 & $\Psi 6.1$ & $\psi 5.6$ \\
\hline Aluminium & 204 & 17,000 & 1,000 \\
\hline Arsenic & 0.013 & 7 & 1 \\
\hline Cadmium & 0.019 & 3.2 & $<0.06$ \\
\hline Calcium & 519 & 12,000 & 26,000 \\
\hline Chromium & 0.080 & 49 & 7.0 \\
\hline Cobalt & 2.61 & 4.6 & 11 \\
\hline Copper & 0.331 & 580 & 0.4 \\
\hline Iron & 689 & 14,000 & 670 \\
\hline Lead & 0.331 & 120 & $<1$ \\
\hline Magnesium & 726 & 2,700 & 2,800 \\
\hline Nickel & 5.18 & 39 & 1.3 \\
\hline Zinc & 16.0 & 1,500 & 47 \\
\hline
\end{tabular}

*Green waste data from representative Perth sample; Пas Kjeldahl nitrogen; $\psi 1$ (sample solid):10 (distilled water) paste test. 
Temperature was very even within treatments averaging a coefficient of variation of $1 \%$ between all treatment replicates at each sampling date and ranging from $19.5-22^{\circ} \mathrm{C}$. The $\mathrm{pH}$ of the control treatment level changed little $(0.05 \mathrm{pH}$ units) over the course of the experiment. Similarly, apart from an initial $0.4 \mathrm{pH}$ unit increase in the sewage treatment, $\mathrm{pH}$ was not seen to increase over the course of the experiment in this treatment either. However, green waste, and green waste and sewage treatments both showed a dramatic increase in $\mathrm{pH}$ after day 37 , to around 5.5 by day 145 . Nevertheless, there appeared to be greater variation in the $\mathrm{pH}$ response with the green waste treatment than for either sewage or even green waste and sewage. Variability within treatments appeared to be primarily due to differences in the date at which probable $\mathrm{SO}_{4}^{-2}$ reduction and hence alkalinity production became established.

Specific conductance appeared to increase in all treatments following addition of organic material, with the greatest increase in the green waste treatment (Fig. 7b). Although there was a slight increase in control specific conductance over the experiment from $9.5-10.5 \mathrm{mS} \mathrm{cm}^{-1}$, specific conductance appeared to decline in all treatments at around the same as alkalinity increased (i.e., day 37). Although treatments containing sewage were very variable between replicates, both treatments containing sewage appeared to decline in solute concentrations greater than did green waste alone.

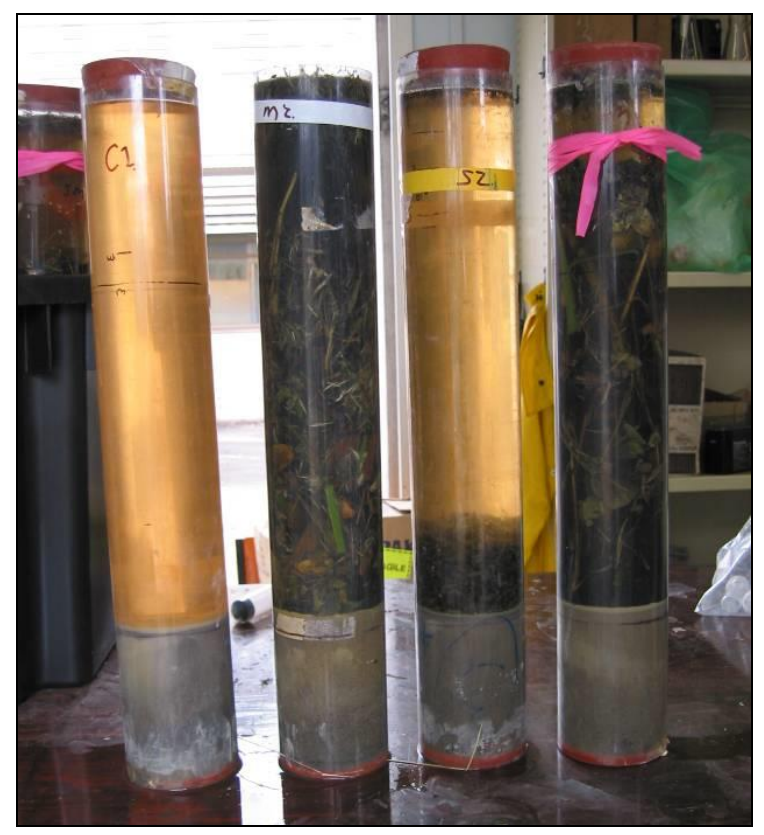

Figure 5. Microcosm cores on day 0. Treatment allocations from left to right are control, green waste, sewage and green waste and sewage. 


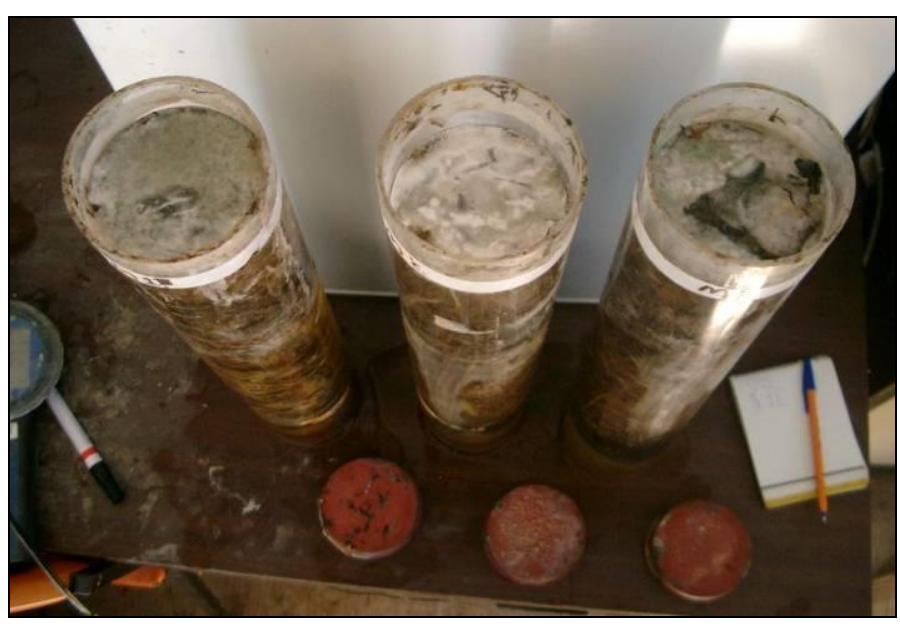

Figure 6. Mould growing on the surface of green waste-only cores at day 72 .

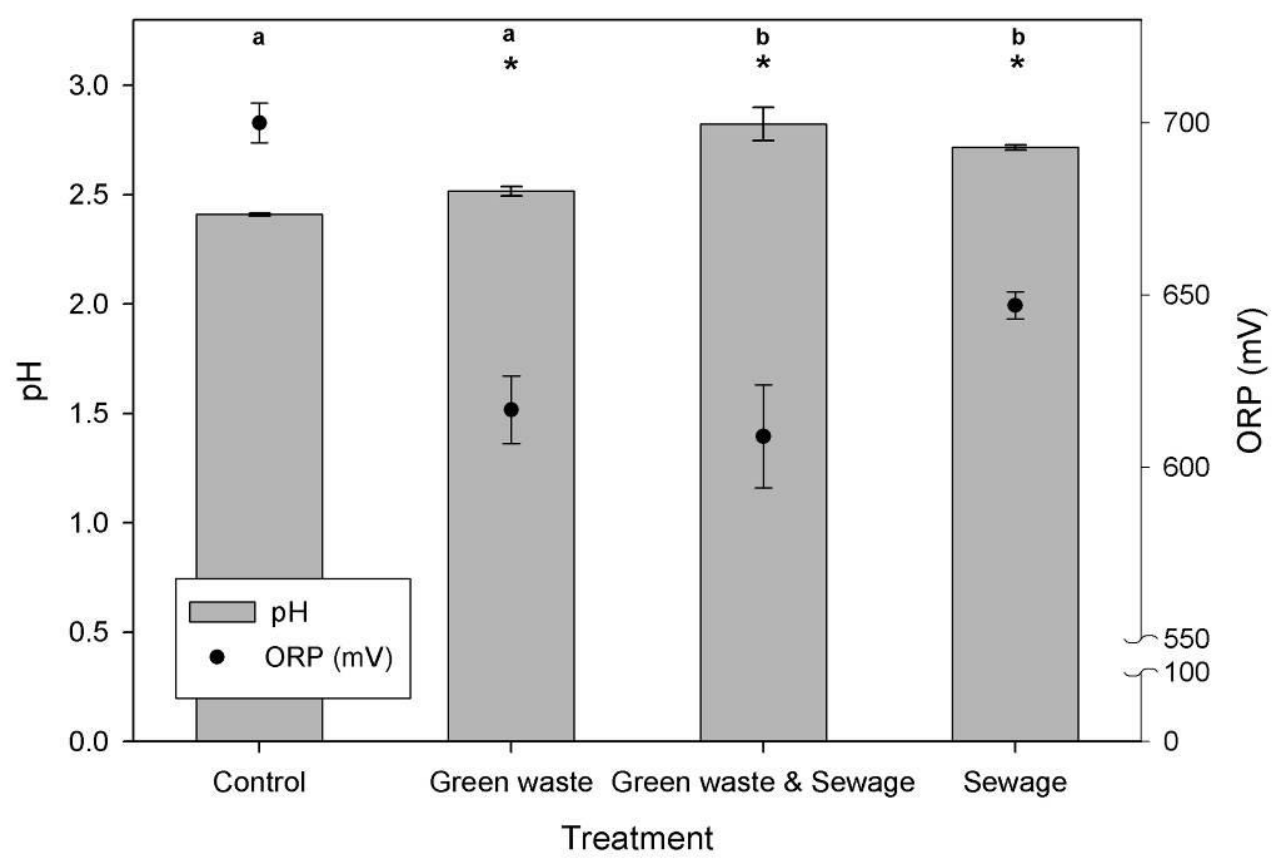

Figure 7. Microcosm core mean $\mathrm{pH}$ and redox potential on day 2 after addition of organic substrates. Error bars indicate single standard errors of the mean. Letters indicates statistically significant differences $(\mathrm{p}<0.05)$ between controls and treatments for $\mathrm{pH}$, and asterisks indicate statistically significant differences $(\mathrm{p}<0.05)$ between controls and treatments for redox. Redox measured with a platinum reference electrode.

Aside from $\mathrm{Fe}$ and $\mathrm{Mg}$ which increased in the green waste treatment; and $\mathrm{Cd}, \mathrm{Ca}, \mathrm{Cu}, \mathrm{Pb}$, and $\mathrm{Zn}$ which increased in the sewage treatment, other solutes had decreased in all treatments by day 86. However the only statistically significant difference in solute concentrations at day 86 were where the $\mathrm{Fe}$ concentrations in sewage treatment was significantly lower than in the 
control; $\mathrm{Cr}$, where both green waste and sewage, and sewage treatment concentrations were lower than control; and $\mathrm{Cu}$ and $\mathrm{Se}$, where both green waste and green waste and sewage treatment concentrations were lower than control (Table 3).

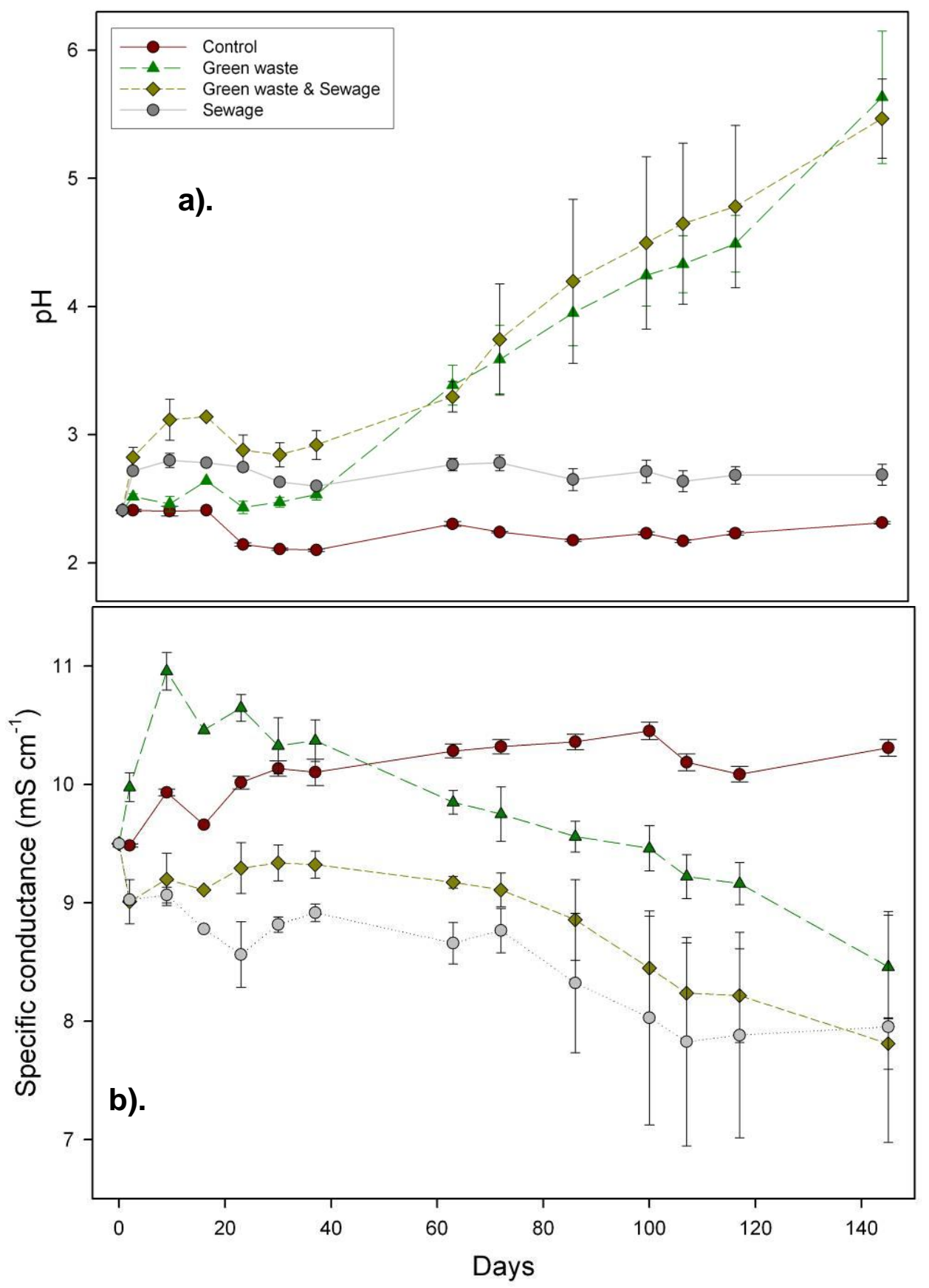

Figure 8. Change in a). $\mathrm{pH}$, and b). specific conductance, of core microcosm treatment levels over time. Error bars indicate single standard errors of the mean. 

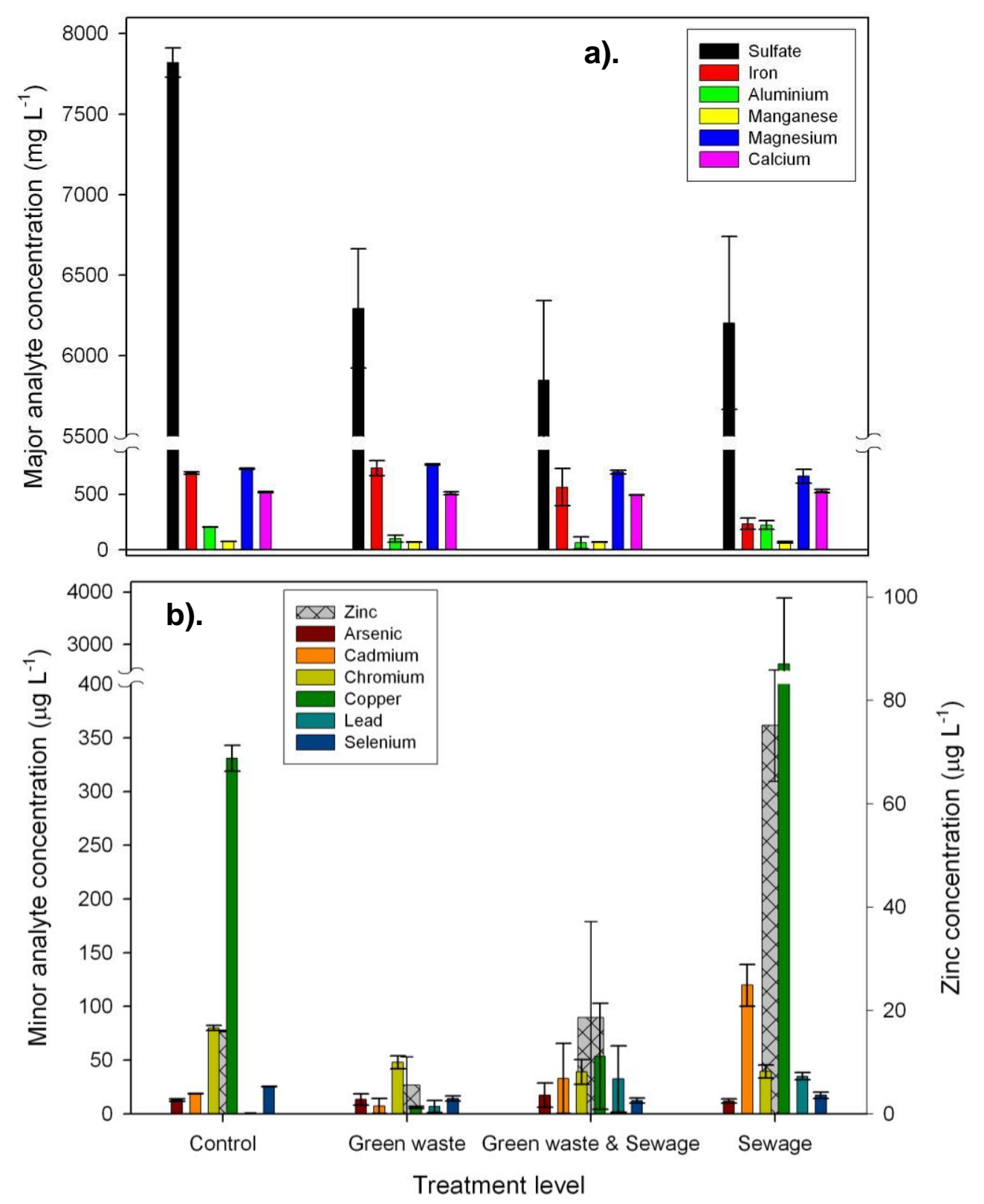

Figure 9. Day 86 concentrations of a). major, and b). minor, analytes for each treatment level. Error bars indicate single standard errors of the mean. 
Table 3. Results of ANOVA test for differences between treatment levels solute concentrations at day 86. Bold type indicates significant difference at $\alpha=0.05$ level.

\begin{tabular}{lcc}
\hline Analyte & F-statistic & p-value \\
\hline Aluminium & $F_{3,11}=3.487$ & 0.070 \\
Arsenic & $F_{3,11}=0.010$ & 0.998 \\
Cadmium & $F_{3,11}=3.302$ & 0.078 \\
Calcium & $F_{3,11}=2.479$ & 0.135 \\
Chromium & $\mathbf{F}_{\mathbf{3 , 1 1}}=\mathbf{4 . 6 4 2}$ & $\mathbf{0 . 0 3 7}$ \\
Copper & $\mathbf{F}_{\mathbf{3 , 1 1}}=\mathbf{8 . 3 3 4}$ & $\mathbf{0 . 0 0 8}$ \\
Iron & $\mathbf{F}_{\mathbf{3 , 1 1}}=\mathbf{6 . 8 1 9}$ & $\mathbf{0 . 0 1 4}$ \\
Lead & $\mathrm{F}_{3,11}=2.899$ & 0.102 \\
Magnesium & $\mathrm{F}_{3,11}=1.635$ & 0.257 \\
Manganese & $\mathrm{F}_{3,11}=0.532$ & 0.673 \\
Selenium & $\mathbf{F}_{\mathbf{3 , 1 1}}=\mathbf{4 . 9 3 6}$ & $\mathbf{0 . 0 3 2}$ \\
Sulfate & $\mathrm{F}_{3,11}=3.441$ & 0.072 \\
Zinc & $\mathrm{F}_{3,11}=3.435$ & 0.072 \\
\hline
\end{tabular}

A Principal Components Analysis (PCA) indicated that addition of organic matter appeared to increase the variability of water chemistry parameters over that of the control (Figure 9). There also appeared to be synergistic effects on variability with the combination of green waste and sewage producing the most varied response between replicates. Addition of green waste moved the water chemistry primarily along the first principal component axis, addition of sewage separated along the second principal component axis. After 86 days, addition of sewage was correlated with increases in dissolved concentrations of the heavy metals $\mathrm{Cd}, \mathrm{Cu}, \mathrm{Pb}$ and $\mathrm{Zn}$; and ammonia. Addition of sewage was correlated with decreases in $\mathrm{Fe}, \mathrm{Cr}, \mathrm{SO}_{4}{ }^{-2}$ and electrical conductivity. Addition of green waste was correlated with increases in $\mathrm{pH}$ and with decreases in dissolved oxygen, redox, $\mathrm{Al}, \mathrm{Ni}, \mathrm{SO}_{4}{ }^{-2}$ and Se. Nevertheless, although more variable, water chemistry correlations with green waste and sewage were very similar to green waste. 


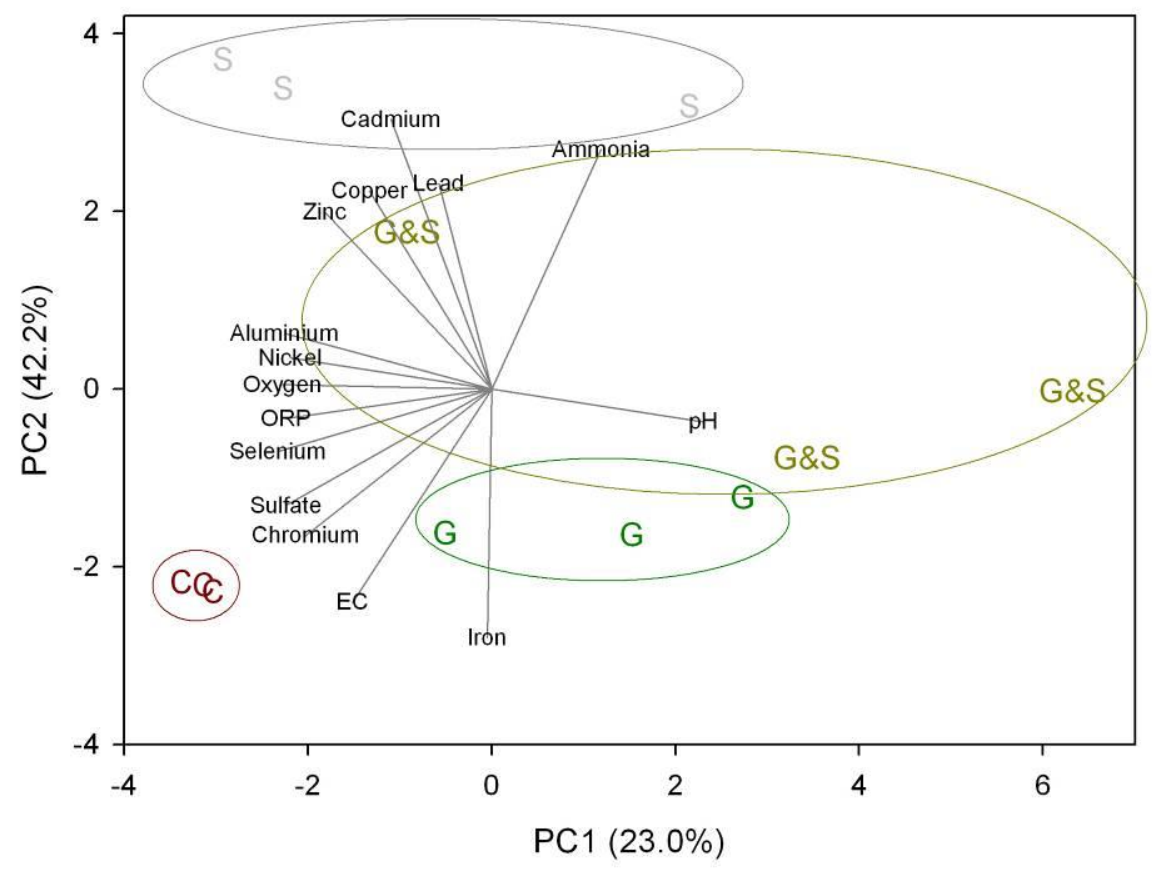

Figure 10. PCA of day 86 microcosm core solute concentrations and physico-chemistry. Vectors indicate variables contributing $|>0.25|$ to an eigenvector. Ellipses represent range of variation within treatment levels.

\section{$\underline{\text { Discussion }}$}

The decrease in $\mathrm{SO}_{4}{ }^{-2}$ concentrations in all of the treatment microcosms provides further support for biological $\mathrm{SO}_{4}{ }^{-2}$ reduction occurring at varying rates and removing cations as precipitates in the dosed mesocosms. However, the success of $\mathrm{SO}_{4}{ }^{-2}$ reduction in low $\mathrm{pH}$ waters appears to be contrary to Postgate's (1984) assertion that $\mathrm{SO}_{4}{ }^{-2}$ reducing bacteria (SRB) activities only occur at $\mathrm{pH}>5$. Nevertheless, published studies some time ago have reported SRB activity at $\mathrm{pH}$ values below this threshold. For example, SRB activity in an acid lake has been found by Herhily and Mills (1985) at pH 2.5, and at pH 2.7 by Gyure et al. (1987). In these studies and our own, it appears that slightly-acid microclimates, facilitated in part by alkalinity produced through some $\mathrm{SO}_{4}{ }^{-2}$ reduction, enabled $\mathrm{SO}_{4}{ }^{-2}$ reducing bacteria to survive at and to chemical reduce $\mathrm{SO}_{4}^{-2}$, producing alkalinity as part of this biological process (Küsel and Dorsch, 2000; Küsel et al., 2001).

Depending on its source, sewage sludge can contain high concentrations of heavy metals (Berrow and Webber, 1971). This is especially so of $\mathrm{Cd}$, which is often concentrated in sewage sludge from vegetables which have been fertilised with inorganic phosphates; a common application in depauperate Australian soils (Nursita et al., in press). Unexpectedly for a nonindustrial content sewage source, the Collinsville sewage also displayed high concentrations for $\mathrm{Ni}, \mathrm{Pb}$, and $\mathrm{Zn}$. However, these high heavy metal concentrations are still unlikely to present a problem over a longer remediation time. Along with Fe, these toxic heavy metals are expected to precipitate out of solution by reaction with $\mathrm{H}_{2} \mathrm{~S}$, such that their toxic effect is removed from 
the water column to levels lower than observed at day 86. Further reduction in biological availability is likely to occur through formation of complexes with organic chelators present as components of the refractory green waste, such as organic acids (Tipping and Hurley, 1992). Nevertheless, the contribution that organic materials may make to the heavy metal burden of a pit lake needs to be considered in the choice of organic materials for remediation. This study found a straight green waste treatment performed similarly to that of green waste and sewage, with fewer heavy metals contributed to the water column. In this respect, remediation strategies may be best placed by choosing green waste as the bulk contribution to electron donors over that of sewage. As discussed, green waste also has an additional advantage of providing organic substances such as humic and fulvic acids with which, heavy metals may directly complex to. Ligand formation between heavy metals and refractory organics will further remove these toxic components from biological availability, albeit at a likely reduced capacity to that of $\mathrm{SO}_{4}{ }^{-2}$ reduction processes (Brown Jr., 2001).

The initiation of alkalinity production in green waste and green waste and sewage in only 37 days is likely to be due to a combination of two important factors unique to this study. Firstly, most other research published to date has occurred in cool temperate areas of Europe and North America e.g., (Benner et al., 2002; Frömmichen et al., 2004; Küsel and Dorsch, 2000; Küsel et al., 2001; Tostche et al., 2003). The higher temperatures experienced in Collinsville, even during the middle of the Dry season $\left(19.5-28.2^{\circ} \mathrm{C}\right)$ are likely to have exponentially increased biochemical rates of carbon diagenesis and metabolism. Seasonal change in ambient temperatures has also been identified as limiting rates of $\mathrm{SO}_{4}{ }^{-2}$ reduction in some experiments with reduced rates of $\mathrm{SO}_{4}^{-2}$ reduction occurring over cooler seasonal periods (Benner et al., 2002; Gammons et al., 2000).

Secondly, the use of largely fresh green waste as opposed to refractory organic substrates such as straw (Frömmichen et al., 2003; Frömmichen et al., 2004), rye grass (Harris and Ragusa, 2000; Harris and Ragusa, 2001), etc., distinguishes this research from many others in the published literature. The greater labile fraction of organic material available in this fresher material may have contributed directly to electron donors for $\mathrm{SO}_{4}{ }^{-2}$ reduction. For example, chlorophyll was seen to be leached from the green waste and it is likely that highly labile sap sugars would have leached also. Consequently, the use of fresh green waste to acid pit lakes, with or without complementary additions of sewage, may prove to be a novel practicable remediation strategy for AMD issues in remote mining locations.

Although these microcosm results are only indicative of the pit lake's water columns in a stratified form, regular monthly monitoring data of three CCP pit lakes over the last 9 months, including GAE, indicate strong thermal stratification at all times. Although the epilimnion may deepen to a few metres under strong forcing winds, even in the middle of the Dry season they remain thermally stratified within the first 2-3 $\mathrm{m}$ due to the rapid heating caused by their high light absorption (photosynthetic coefficient of attenuation of 0.28 , author's unpublished data). This heating rate may decrease as Fe precipitates from the water column, however the large mass of woody green waste resting on the benthos in a field-scale trial will nevertheless also provide for hypolimnion stability though increased bed roughness and consequent resistance to wind forcing of the water column.

Mine water research and management is a very new and rapidly developing field (Wolkersdorfer, 2004). The corrective measures for very acidic hardwater mining lakes also greatly differ from those in use for eutrophication control (Klapper, 2003). As a consequence 
both researchers and regulatory agencies need to maintain an open-mind to treatment solution options for these unique environmental issues. Best practice AMD pit lake treatment is likely to be required to be made on a case-by-case basis where potential pit lake end uses and availability of organic substrates have been identified and a remediation strategy has consequently only then been constructed. Part of the challenge for both mining companies and regulatory waterbody managers with this assessment will be the ability to think laterally as to what the current values of the pit lake are, what treatments may be feasible, and what type of system (water quality and quantity) is desirable as an end result for either social, environmental or other enduses (Doupé and Lymbery, 2005).

\section{Current and future projects}

Another microcosm core experiment is also being completed by our CSML research team. This study will focus on the effect of both different organic loading rates and the effects of the addition of small amounts of lime on alkalinity production, and is based in our Perth laboratories for greater ease of experimental control and manipulation. The dosing of organic matter in this lake would be expected to continue over a few months, to be within the capacity of the wastewater treatment plants. For long-term remediation purposes, organic matter additions are expected to be required at an ongoing, albeit lower, dosing rate. The use of refractory organic forms such as woody green waste may also be advantageous to long-term remediation efforts, in that they will continue to degrade into more labile fractions available for $\mathrm{SO}_{4}{ }^{-2}$ reducers over long periods of time.

Water column stratification is expected to remain strong in this remediated pit lake due to even-temperature and hot tropical climate in which it exists. Nonetheless, depth and duration of stratification will remain an important decider in the efficacy and viability of $\mathrm{SO}_{4}{ }^{-2}$ reduction as a remediation measure in any pit lake (Martin et al., 2003; McNee et al., 2003) and to this end thermocouples studies and consequent one-dimensional modelling studies of changes in mixing regimes of a dosed lake with DYRESM software (Imberger and Patterson, 1981) are also planned.

The application of the science now requires on-site experiments at field scale to demonstrate this new technology of remediation with bulk low-grade organic sources. To this end we have begun a full-field scale evaluation of the efficacy of green waste and sewage additions to a section of the GAE pit lake (Fig. 2). This pit lake is typical of those of the CCP mining lease, as it is a highly acidic terminal lake with high concentrations of dissolved solutes. We have sectioned-off approximately $1 / 4$ of the western surface area of this lake by pushing overburden along a $100 \mathrm{~m}$ wall across the narrowest width of the lake (Fig. 2). This western portion of the lake will form a dosed treatment, receiving sewage and green waste over the next six months. The remaining $3 / 4$ section of the lake, along with two other, similar mine pit lakes, will function as control treatments during this time, and in the 12 months monitoring thereafter.

\section{Acknowledgements}

Thanks to Collinsville Coal Project (Xstrata Coal Queensland) for logistical support and lease access. Thanks also to René Frömmichen for valuable discussion and advice. Finally thanks to the three ICARD reviewers; Devin Castendyk, Brain Park and Jim Jonas whom improved upon a draft of this paper. This project was made possible by Australian Coal Association Research Council grant C14052. 


\section{Literature Cited}

ANZECC/ARMCANZ, 2000. Australian and New Zealand guidelines for fresh and marine water quality. National Water Quality Management Strategy Paper No 4, Australian and New Zealand Environment and Conservation Council \& Agriculture and Resource Management Council of Australia and New Zealand, Canberra.

APHA, 1998. Standard methods for the examination of water and wastewater. American Public Health Association, American Water Works Association, Water Environment Federation, Washington DC, USA.

Benner, S.G., Blowes, D.W., Ptacek, C.J. and Mayer, K.U., 2002. Rates of sulfate reduction and metal sulfide precipitation in a permeable reactive barrier. Applied Geochemistry, 17(3): 301-320. http://dx.doi.org/10.1016/S0883-2927(01)00084-1.

Berrow, M.L. and Webber, J., 1971. Trace elements in sewage sludges. Journal of the Science of Food and Agriculture, 23: 93-100. http://dx.doi.org/10.1002/jsfa.2740230112.

Borg, H. and Holm, K., 2001. Influence of acidification and liming on the distribution of trace elements in surface waters. Water, Air, \& Soil Pollution, 130: 1757-1762. http://dx.doi.org/10.1023/A:1013913614863.

Brown Jr., G.E., 2001. Surface science. How minerals react with water. Science, 294(5540): 67 70. http://dx.doi.org/10.1126/science.1063544.

Castro, J.M. and Moore, J.N., 1997. Pit lakes: their characteristics and the potential for their remediation. Environmental Geology, 39(1): 254-260.

Castro, J.M., Wielinga, B.W., Gannon, J.E. and Moore, J.N., 1999. Stimulation of sulfatereducing bacteria in lake water from a former open-pit mine through addition of organic waste. Water Environment Research, 218-223. http://dx.doi.org/10.2175/106143098X121806.

Clarke, K.R. and Warwick, R.M., 2001. Change in marine communities: an approach to statistical analysis and interpretation. Plymouth Marine Laboratory, Plymouth, 144 pp.

Commonwealth of Australia Bureau of Meteorology, 09/02/2005. Collinsville climate averages.

Davies, N. and Willcocks, J., 1992. Climate variability in the Fitzroy Catchment. In: L.J. Duivenvoorden, D.F. Yule, L.E. Fairweather and A.G. Lawrie (Editors), Proceedings of the Fitzroy Catchment Symposium, University of Central Queensland. University of Central Queensland, Queensland Department of Primary Industries, Capricorn Conservation Council and United Grazers Association, Rockhampton, Queensland, Australia.

Dillon, P.J., Evans, H.E. and Girard, R., 1997. Hypolimnetic alkalinity generation in two dilute, oligotrophic lakes in Ontario Canada. Water, Air, \& Soil Pollution, 99: 373-380. http://dx.doi.org/10.1007/BF02406877.

Doupé, R.G. and Lymbery, A.J., 2005. Environmental risks associated with beneficial end uses of mine lakes in southwestern Australia. Mine Water and the Environment, 24(3): 134-138. http://dx.doi.org/10.1007/s10230-005-0084-0. 
Drury, W.J., 1999. Treatment of acid mine drainage with anaerobic solid substrate reactors. Water Environment $\quad$ Research, 71(6): 1244-1250. http://dx.doi.org/10.2175/106143096X122375

Drury, W.J., 2000. Modelling of sulfate reduction in anaerobic solid substrate bioreactors for mine drainage treatment. Mine Water and the Environment, 19(1): 18-28. http://dx.doi.org/10.1007/BF02687262.

Fallon, K., 1994. Collinsville Coal Company acid mine drainage survey. 0505, Hydrometallurgy Research Laboratories, Albion, Australia.

Frömmichen, R., Kellner, S. and Friese, K., 2003. Sediment conditioning with organic and/or inorganic carbon sources as a first step in alkalinity generation of acid mine pit lake water $(\mathrm{pH}$ 2-3). Environmental Science and Technology, 37: 1414-1421. http://dx.doi.org/10.1021/es026131c.

Frömmichen, R., Wendt-Potthoff, K., Friese, K. and Fischer, R., 2004. Microcosm studies for neutralization of hypolimnic acid mine lake water $(\mathrm{pH} 2.6)$. Environmental Science and Technology, 38: 1877-1887. http://dx.doi.org/10.1021/es034863e.

Fyson, A., Nixdorf, B., Kalin, M. and Steinberg, C.E.W., 1998. Mesocosm studies to assess acidity removal from acidic mine lakes through controlled eutrophication. Ecological Engineering, 10: 229-245. http://dx.doi.org/10.1016/S0925-8574(98)00007-X.

Gammons, C.H., Drury, W.J. and Youning, L., 2000. Seasonal influences on heavy metal attenuation in an anaerobic treatment wetlands facility, Butte, Montana., 5th International Conference on Acid Rock Drainage, Denver, USA, pp. 1159-1168.

Geller, W., Wendt-Potthoff, K. and Koschorreck, M., 2003. In situ bioremediation of acid mining lakes by addition of organic substrate and lime, Sudbury 2003 - Mining and the Environment, Laurentian University - Sudbury, Ontario, Canada.

Gibert, O., de Pablo, J., Cortina, J.L. and Ayora, C., 2002. Treatment of acid mine drainage by sulphate-reducing bacteria using permeable reactive barriers: a review from laboratory to full-scale experiments. Reviews in Environmental Science and Biotechnology, 1: 327-333. http://dx.doi.org/10.1023/A:1023227616422

Gusek, J.J., 2002. In situ AMD treatment in abandoned underground coal mines - a look at an innovative concept, Lakewood Colorado.

Gyure, R.A., Konopka, A., Brooks, A. and Doemel, W., 1987. Algal and bacterial activities in acidic (pH 3) strip mine lakes. Applied and Environmental Microbiology, 53: 2069-2076.

Hard, B.C., Higgins, J.P. and Mattes, A., 2003. Bioremediation of acid rock drainage using sulfate-reducing bacteria, Sudbury 2003 - Mining and the Environment, Laurentian University - Sudbury, Ontario, Canada.

Harries, J., 1997. Acid mine drainage in Australia. 125, Supervising Scientist, Darwin.

Harris, M.A. and Ragusa, S., 2000. Bacterial mitigation of pollutants in acid drainage using decomposable plant material and sludge. Environmental Geology, 40((1-2)): 195-215. http://dx.doi.org/10.1007/s002540000138. 
Harris, M.A. and Ragusa, S., 2001. Bioremediation of acid mine drainage using decomposable plant material in a constant flow bioreactor. Environmental Geology, 40(10): 1192-1204. http://dx.doi.org/10.1007/s002540100298.

Herhily, A.T. and Mills, A.L., 1985. Sulfate reduction in freshwater sediments receiving acid mine drainage. Applied Environmental Microbiology, 49: 179-186.

Imberger, J. and Patterson, J.C., 1981. A dynamic reservoir simulation model - DYRESM:5. In: H.B. Fischer (Editor), Transport Models for Inland and Coastal Waters. Academic Press, New York, pp. 310-361. http://dx.doi.org/10.1016/b978-0-12-258152-6.50014-2.

Klapper, H., 2003. Technologies for lake restoration. Journal of Limnology, 62 (Supplement 1): 73-90. http://dx.doi.org/10.4081/jlimnol.2003.s1.73

Kleeberg, A., 1998. The quantification of sulfate reduction in sulfate-rich freshwater lakes - a means for predicting the eutrophication process of acidic mining lakes. Water, Air, and Soil Pollution, 108: 365-374. http://dx.doi.org/10.1023/A:1005194404417.

Kolmert, A. and Johnson, D.B., 2001. Remediation of acidic waste waters using immobilised, acidophilic sulfate-reducing bacteria. Journal of Chemical Technology \& Biotechnology, 76(8): 836-843. http://dx.doi.org/10.1002/jctb.453.

Küsel, K. and Dorsch, T., 2000. Effect of supplemental electron donors on the microbial reduction of $\mathrm{Fe}(\mathrm{III})$, sulfate, and $\mathrm{CO}_{2}$ in mining-impacted freshwater lake sediments. Microbial Ecology, 40: 238-249.

Küsel, K., Rotha, U., Trinkwaltera, T. and Peifferb, S., 2001. Effect of pH on the anaerobic microbial cycling of sulfur in mining-impacted freshwater lake sediments. Environmental and Experimental Botany, 46(3): 213-223. http://dx.doi.org/10.1016/S0098-8472(01)00103-4

Lessmann, D., Fyson, A. and Nixdorf, B., 2000. Phytoplankton of the extremely acidic mining lakes of Lusatia (Germany) with $\mathrm{pH}<3$. Hydrobiologia, 433: 123-128. http://dx.doi.org/10.1023/A:1004018722898.

Martin, A. et al., 2003. Field-scale assessment of bioremediation strategies for two pit lakes using limnocorrals, 6th International Conference on Acid Rock Drainage (ICARD). Australasian Institute of Mining and Metallurgy, Cairns, Australia.

McNee, J. et al., 2003. The physical, chemical and biological dynamics of two contrasting pit lakes: Implications for pit lake bio-remediation, Sudbury 2003 - Mining and the Environment, Laurentian University - Sudbury, Ontario, Canada.

Nursita, A.I., Singh, B. and Lees, E., in press. The effects of cadmium, copper, lead, and zinc on the growth and reproduction of Proisotoma minuta Tullberg (Collembola). Ecotoxicology and Environmental Safety. http://dx.doi.org/10.1016/j.ecoenv.2004.05.001.

Pöhler, I., Wenderoth, D.F., Wendt-Potthoff, K. and Höfle, M.G., 2002. Bacterioplankton community structure and dynamics in enclosures during bioremediation experiments in an acid mining lake. Water, Air, \& Soil Pollution: Focus, 2(3): 111-121. http://dx.doi.org/10.1023/A:1019951612385.

Postgate, J.R., 1984. The sulphate-reducing bacteria. Cambridge University Press, New York, $208 \mathrm{pp}$. 
Praharaj, T. and Fortin, D., 2004. Indicators of microbial sulfate reduction in acidic sulfide-rich mine tailings. Geomicrobiology Journal, 21(7): 457-467. http://dx.doi.org/10.1080/01490450490505428.

PRIMER-E Ltd, 2001. PRIMER. Plymouth Marine Laboratory, Plymouth.

SPSS Inc., 2000. SigmaPlot for Windows. SPSS Inc., Chicago.

Tipping, E. and Hurley, M.A., 1992. A unifying model of cation binding by humic substances. Geochimica et Cosmochimica Acta, 56: 3627-3641. http://dx.doi.org/10.1016/00167037(92)90158-F.

Tostche, O., Fyson, A. and Steinberg, C., 2003. Neutralizing extremely acidic mining lakes by chemical and microbial treatment - mesocosm studies., Sudbury 2003: Mining and the environment, Laurentian University - Sudbury, Ontario, Canada.

Tuttle, J.H., Dugan, P.R. and Rendles, C.I., 1969. Microbial sulfate reduction and its potential utility as an acid mine water pollution abatement procedure. Applied Microbiology, 17: 297302.

Waybrant, K.R., Blowes, D.W. and Ptacek, C.J., 1998. Selection of reactive mixtures for use in permeable reactive walls for treatment of mine drainage. Environmental Science and Technology, 32(13): 1972-1979. http://dx.doi.org/10.1021/es9703335

Wendt-Potthoff, K., Frömmichen, R., Herzsprung, P. and Koschorreck, M., 2002. Microbial $\mathrm{Fe}(\mathrm{III})$ reduction in acidic mining lake sediments after addition of an organic substrate and lime. Water, Air, \& Soil Pollution: Focus, 2(3): 81-96. http://dx.doi.org/10.1023/A:1019959814202.

Wolkersdorfer, C., 2004. Mine water literature in ISI's Science Citation Index Expanded ${ }^{\mathrm{TM}}$. Mine Water and the Environment, 23: 96-99. http://dx.doi.org/10.1007/s10230-004-0046-y. 